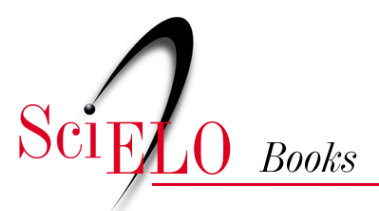

ed

\title{
Uma visão integrada dos impactos ambientais no estado do Rio de Janeiro
}

\author{
Tereza Coni Aguiar
}

\section{SciELO Books / SciELO Livros / SciELO Libros}

AGUIAR, T.C. Uma visão integrada dos impactos ambientais no estado do Rio de Janeiro. In: MARAFON, G.J., and RIBEIRO, M.A. orgs. Revisitando o território fluminense, VI [online]. Rio de Janeiro: EDUERJ, 2017, pp. 65-84. ISBN: 978-85-7511-457-5.

https://doi.org/10.7476/9788575114575.0005.

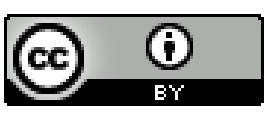

All the contents of this work, except where otherwise noted, is licensed under a Creative Commons Attribution 4.0 International license.

Todo o conteúdo deste trabalho, exceto quando houver ressalva, é publicado sob a licença Creative Commons Atribição 4.0.

Todo el contenido de esta obra, excepto donde se indique lo contrario, está bajo licencia de la licencia $\underline{\text { Creative Commons }}$ Reconocimento 4.0. 


\section{Uma visão integrada dos impactos ambientais no estado do Rio de Janeiro}

Tereza Coni Aguiar

\section{Introdução}

0 estado do Rio de Janeiro apresenta uma grande variedade de ecossistemas e de paisagens. No entanto, em virtude do processo de ocupação em seu território, iniciado no século XVI, vem sofrendo perdas significativas em seu ambiente natural, além do risco de degradação ambiental. Observa-se que, ao longo de sua formação socioespacial, as atividades ligadas à agricultura, à pecuária, ao extrativismo, ao turismo e à indústria, além da urbanização, expandiram-se pelo território fluminense sem levar em conta a preservação de seus recursos naturais (Galvão, 2009). Houve também uma grande concentração econômica, populacional, espacial e decisória na região metropolitana, especialmente em seu núcleo, a cidade do Rio de Janeiro, o que resultou na fraca articulação entre as diversas regiōes fluminenses (Abreu, 1987; Ribeiro e O’Neil, 2012).

Recentemente, o estado vem passando por inúmeras transformações em sua estrutura produtiva, em função da maior inserção na economia global. As atividades implantadas são conduzidas por empresas e/ou interesses multinacionais, trazendo mudanças significativas ao espaço fluminense. Essa etapa da economia fluminense, em função da nova globalização, caracteriza-se pelo fortalecimento das empresas privadas e o enfraquecimento de iniciativas governamentais em diversos níveis; por mudanças em sua estrutura produtiva e no território, trazidas pelos investimentos externos, nos diferentes setores econômicos, muitos deles relacionados à implantação de projetos de grande porte. O setor de petróleo foi um dos principais atores dessa inflexão econômica, ocorrida a partir da década de 1990 e impulsionada pela Lei $\mathrm{n}^{\mathrm{o}} .9 .478 / 97$, que atraiu numerosas empresas multinacionais ligadas ao petróleo. A fase de exploração do pré-sal, iniciada em meados da década de 2010, veio fortalecer ainda mais o setor de petróleo no ERJ.

\footnotetext{
1 Doutora em Geografia (UFF, 2012).
} 
As atividades ligadas ao petróleo atraíram empresas prestadoras de serviços, aumentaram a circulação de bens e pessoas, elevaram o fluxo migratório e ativaram os setores de construção civil e do mercado imobiliário. Essas atividades não apenas se mostraram fundamentais para a reestruturação econômica e produtiva das regiōes de exploração do petróleo, como o Norte fluminense, como também contribuíram, efetivamente, para alavancar o crescimento econômico e a vida urbana em outras áreas. Tornaram-se, pois, um fator importante no estímulo de novos investimentos nos diversos setores da economia e nas demais regióes do estado.

$\mathrm{Na}$ atualidade, a análise do território fluminense sob o ponto de vista ambiental torna-se oportuna por tornar possível avaliar ações que conduzem a alterações significativas na geografia do estado. Essas ações têm provocado intensa mobilidade espacial da população, modificações na paisagem, em seu uso e suas funçôes, além de gerar problemas ambientais com impacto em diversos recursos naturais, bem como no patrimônio natural e cultural. Também geram conflito ambiental nas diversas regiões em que se localizam (Ribeiro e O’Neill, 2012).

Os problemas ambientais verificados nas diferentes áreas do território fluminense também estão associados à expansão metropolitana, aos setores turístico e imobiliário, à indústria pesada, bem como à sua integração à logística de transporte global. Os locais em que essas atividades ocorrem são os mais afetados pelo contexto de reestruturação produtiva na fase de globalização avançada.

Neste artigo, o interesse se volta para uma visão integrada desses problemas e impactos ambientais, suas possíveis consequências e as possibilidades de se pensarem formas de minimizá-las.

\section{Visão conceitual e metodologia}

As questōes ambientais da atualidade empregam um número consideravelmente amplo de conceitos nas mais diversas situaçóes encontradas. Entretanto, com o propósito de colaborar para a compreensão de um conjunto de problemas relativos ao meio ambiente, num tempo e num espaço determinados, torna-se fundamental aplicar maior precisão nos respectivos enunciados. Assim, este artigo busca, inicialmente, apresentar os principais conceitos que se articulam para melhor compreender a problemática ambiental no território fluminense, especialmente nas três últimas décadas.

Muitos estudos fazem referência a uma visão integrada, buscando entender as relações existentes entre os elementos da natureza e da sociedade entre si e no conjunto. Em outras palavras, traça-se uma abordagem que conecte as diferentes formas de utilização do território, os recursos naturais e os elementos físicos. Essa visão ampla é fundamental para a compreensão dos problemas, impactos e conflitos, bem como para a busca de soluções e políticas adequadas. Uma visão limitada, que discuta apenas os processos de modo isolado, é uma das principais causas para a persistência de problemas (Tucci, 2001). Entretanto, "muitas pesquisas ainda analisam, de forma fragmentada e dissociada, os elementos da natureza e os da sociedade, esquecendo-se de que o homem não vive isolado, mas em sociedade, e interage continuamente com todos os elementos da natureza” (Aguiar, 2014, p. 117). Portanto, a adoção de um foco integrado permite que a análise do ambiente colabore para a reflexão de prováveis cenários, pensando-se em estratégias de médio e longo prazos, com vistas a não agravar a situação encontrada. 
Outro aspecto relevante que a avaliação integrada possibilita é a articulação dos problemas, impactos e conflitos em seu respectivo contexto. O espaço geográfico - chave para se compreender o que se passa na sociedade globalizada - vai-se desvendando pelo entrelaçamento do contexto, dos problemas, dos impactos e dos conflitos em que as dimensões da natureza e da sociedade estão em contínuo inter-relacionamento.

Os problemas ambientais não são fenômenos recentes; acompanham a humanidade desde a Idade do Bronze, ou seja, desde 3.000 a.C. (Chew, 2001). No entanto, o que sobressai na atualidade é a proporção com que atingem, em termos espaciais, os diversos elementos da natureza e da sociedade que os envolvem.

Um problema ambiental pode ser considerado a partir da ausência de determinadas condições no ambiente físico ou na sociedade que venham a afetar a qualidade de vida e do ambiente. Porém, segundo Bolea (1977, p. 13), "diz-se que há um impacto ambiental quando uma ação ou atividade produz uma alteração no meio ou em algum dos seus componentes".

Com o avanço da tomada de consciência em relação ao meio ambiente, proporcionada, principalmente, pelos inúmeros desastres ambientais e por importantes conferências mundiais sobre o meio ambiente, desde Estocolmo, em 1972, cresceu a consciência acerca da necessidade de se ter maior conhecimento sobre os impactos, interessando saber a dimensão alcançada e a intensidade das ações humanas provocadas pelas atividades econômicas (Christofoletti, 1997).

A Resolução no 1, de 23 de janeiro de 1986, do Conselho Nacional do Meio Ambiente (Conama), define impacto ambiental como "qualquer alteração das propriedades físicas, químicas e biológicas do meio ambiente, causada por qualquer forma de matéria ou energia resultante de atividades humanas" (Brasil, 2008). A geógrafa Susan Parker, em The Encyclopaedic Dictionary of Physical Geography (apud Christofoletti, 1997, pp. 131-2), o define como "a mudança sensível, positiva ou negativa, nas condiçôes de saúde e bem-estar das pessoas e na estabilidade dos ecossistemas da qual depende a sobrevivência humana". Segundo Coelho (2001, p. 24), impacto ambiental é, portanto,

\begin{abstract}
o processo de mudanças sociais e ecológicas causado por perturbações (uma nova ocupação e/ou construção de um objeto novo: uma usina, uma estrada ou uma indústria) no ambiente. Diz respeito ainda à evolução conjunta das condições sociais e ecológicas estimulada pelos impulsos das relações entre forças externas e internas à unidade espacial e ecológica, histórica ou socialmente determinada. É a relação entre sociedade e natureza que se transforma diferencial e dinamicamente. Os impactos ambientais são escritos no tempo e incidem diferecialmente, alterando as estruturas das classes sociais e reestruturando o espaço.
\end{abstract}

$\mathrm{Na}$ fase atual da globalização, quando se procura avaliar os impactos ambientais, depara-se com a complexidade advinda da dificuldade de se separar o impacto no ambiente físico do impacto causado à sociedade (Coelho, 2001). Na realidade, os impactos alteram mutuamente as condiçöes naturais, culturais, sociais, econômicas e históricas. Considera-se, portanto, impacto ambiental o resultado de um processo de mudanças causadas no ambiente, em determinada área e por determinado tempo, provocadas por pertubaçōes ou interferências concretas, advindas de novas atividades e ocupações. Com frequência, essas transformações levam a perdas da identidade, do mundo simbólico e das re- 
laçôes sociais afetivas. Dessa maneira, os impactos podem interferir, de forma direta ou indireta, no meio ambiente como um todo ou tão somente em um ou mais elementos da natureza ou da sociedade.

Em virtude da diversidade de ambientes e formas de ocupação, procura-se considerar, ao se estudarem os impactos, as singularidades presentes, levando-se em conta aspectos como: localização, distância dos centros, crescimento populacional, densidade demográfica, atividades predominantes, classes sociais envolvidas, características topográficas, geológicas e da vegetação, entre outros (Aguiar, 2012). Por conseguinte, o estudo do impacto ambiental deve comprometer-se com a análise dessas particularidades, buscando-se o respectivo grau de gravidade.

No que concerne à elaboração de diagnósticos e estudos ambientais, é possível afirmar que a questão dos conflitos nem sempre é identificada e bem avaliada (Agra Filho, 2008). Esse conceito merece maior atenção, pois houve poucos avanços teórico-metodológicos nesse quesito (Bredariol, 2001). Os conflitos ambientais podem ser definidos como decorrentes das formas de relação entre dois ou mais segmentos sociais que apresentam interesses incompatíveis, no uso ou na apropriação de determinado recurso natural, vindo ou não a gerar impacto na natureza (Aguiar, 2012; Cunha, 2003; IBGE, 1997). Embora os conflitos prevaleçam entre atividades econômicas, também ocorrem entre grupos distintos da população e entre a população e determinadas atividades e/ou empreendimentos.

Quando nos voltamos para os efeitos da urbanização sobre o meio ambiente, percebemos ainda a "ausência de uma teoria dos processos ambientais integradora das dimensões físicas, político-sociais, socioculturais e espaciais" (Coelho, 2001, p. 21). De fato, as questôes relacionadas ao ambiente construído das cidades estão longe de ser equacionadas tão somente pelo emprego de metodologias relativas aos diagnósticos geoambientais baseados no levantamento de características físiográficas, potencialidades, vulnerabilidades, estabilidades e usos. Nos estudos ambientais urbanos, não é possível neglicenciar as condições físicas ou as complexas condições socioeconômicas que interagem nas cidades. Concorda-se com Chew (2001) quando ele afirma que a urbanização, ao utilizar intensamente os recursos naturais, conduziu a alteraçôes tanto no entorno imediato quanto nas áreas mais remotas. Com frequência, os espaços nas cidades foram utilizados sem o devido respeito às suas características físicas. Esse uso inadequado causou sérios problemas, como, por exemplo, a alteração da paisagem, enchentes, deslizamento de terras e até mesmo a proliferação de vetores de doenças. A urbanização ainda esteve associada, nas diversas civilizaçóes, ao desmatamento, ao desequilíbrio hídrico e à poluição do ar e das águas dos rios (Aguiar, 2014).

Os estudos que abarcam os problemas, impactos e conflitos ambientais na atualidade, quando os processos de globalização estão intensificados, devem ser avaliados levando-se em conta determinados fatores, como extensão, ritmo, número de elementos envolvidos, capacidade de gerar problemas, gravidade que assumem em relação ao contexto e número de pessoas afetadas, entre outros. Tal exame pode conduzir ao entendimento de fenômenos de alta gravidade, cujas consequências são imprevisíveis, podendo ser definidos como um processo de degradação ambiental. O conceito de degradação ambiental, apoiado na concepção de Chew (2001), pode ser entendido como

a consequência do modo como as civilizações interagem com o meio natural em função da forma como estão organizadas as diversas atividades econômicas e seus modos de vida. O nível intensivo do uso dos recursos naturais, o estilo de vida, o consumo excessivo e extravagante, como ocorreu em diversas civilizações, podem ocasionar o que ele denominou de stress ecológico. [...] O desastre ambiental, ao 
atingir esse nível, pode interferir na capacidade reprodutiva de determinada civilização, ocasionando o seu declínio e a sua decadência (Aguiar, 2014, p. 116).

Chew (2001) atribui ainda a degradação principalmente aos processos de acumulação de capital e de urbanização, bem como ao intenso crescimento demográfico, com o aumento da população de forma exponencial. Esses três fenômenos foram reponsáveis por grandes perdas do ponto de vista ecológico, notadamente o desmatamento e a transformação física da paisagem (idem, ibidem). A degradação ambiental ocorre em situações-limite, quando vários elementos da natureza são impactados, abrangendo o ambiente como um todo.

Entende-se que a degradação ambiental tem uma dinâmica própria e uma evolução de acordo com as características locais, sendo causada por um conjunto de fatores que se relacionam de forma sistêmica (Nascimento, 2013). A degradação é um processo complexo que está associado a formas inadequadas de manejo da terra, à erosão dos solos, às mudanças climáticas, a grandes extensões desflorestadas e à urbanização. Nascimento também enfatiza que as atividades econômicas é que causam impacto e conduzem à degradação. Nas áreas tropicais, por exemplo, a desestabilização do ambiente pode desencadear ou até mesmo acirrar vários problemas, como intemperismo, lixiviação dos solos, instabilidade das encostas e degradação ambiental generalizada (idem, ibidem).

Para a identificação e a compreensão dos impactos e conflitos ambientais no estado do Rio de Janeiro, conta-se com um acervo de pesquisas, estudos e relatórios elaborados pelo meio acadêmico, por órgãos públicos e ONGs, na última década, documentos que contribuíram para o melhor entendimento dos processos que se encontram em curso no território fluminense. Além desse vasto material bibliográfico, contou-se, para a elaboração deste artigo, com informações oficiais, dados e várias reportagens de jornais e revistas pertencentes ao arquivo da autora. Conta-se também com pesquisas realizadas pela própria em diferentes áreas do estado do Rio de Janeiro.

Para a análise da distribuição espacial do impacto ambiental, optou-se pela divisão regional do estado do Rio de Janeiro tal como adotada pela Lei Estadual no 1.227/87. Desde então, esse recorte regional passou por algumas alterações quanto à denominação e à sua composição (Ceperj, 2014). As chamadas regiōes de governo, com seus respectivos municípios, totalizam oito unidades. São elas: Metropolitana, Noroeste Fluminense, Norte fluminense, Baixadas Litorâneas, Serrana, Centro-Sul Fluminense, Médio Paraíba e Costa Verde, englobando 92 municípios (Quadro 1).

Quadro 1. Regiōes de governo, municípios e população do estado do Rio de Janeiro

\begin{tabular}{|l|l|}
\hline $\begin{array}{l}\text { Regiōes/ } \\
\text { População 2010* }\end{array}$ & Municípios \\
\hline $\begin{array}{l}\text { Metropolitana } \\
11.945 .532 \text { hab. }\end{array}$ & $\begin{array}{l}\text { Cachoeiras de Macacu, Rio Bonito, Itaguaí, Seropédica, Rio de Janeiro, Nilópolis, Quei- } \\
\text { mados, Japeri, Paracambi, Nova Iguaçu, Belford Roxo, São João de Meriti, Duque de } \\
\text { Caxias, Magé, Guapimirim, Itaboraí, Tanguá, Maricá, Mesquita, Niterói e São Gonçalo }\end{array}$ \\
\hline $\begin{array}{l}\text { Noroeste Fluminense } \\
317.493 \text { hab. }\end{array}$ & $\begin{array}{l}\text { Varre-Sai, Porciúncula, Natividade, Laje do Muriaé, Itaperuna, Bom Jesus de Itabapo- } \\
\text { ana, São José de Ubá, Miracema, Santo Antônio de Pádua, Aperibé, Itaocara, Cambuci } \\
\text { e Italva }\end{array}$ \\
\hline
\end{tabular}




\begin{tabular}{|c|c|}
\hline $\begin{array}{l}\text { Regiōes/ } \\
\text { População 2010* }\end{array}$ & Municípios \\
\hline $\begin{array}{l}\text { Norte Fluminense } \\
849.515 \text { hab. }\end{array}$ & $\begin{array}{l}\text { São Francisco de Itabapoana, Cardoso Moreira, São Fidélis, Campos dos Goytacazes, São } \\
\text { João da Barra, Quissamã, Conceição de Macabu, Carapebus e Macaé }\end{array}$ \\
\hline $\begin{array}{l}\text { Baixadas Litorâneas } \\
700.842 \text { hab. }\end{array}$ & $\begin{array}{l}\text { Rio das Ostras, Casimiro de Abreu, Silva Jardim, Cabo Frio, Araruama, Saquarema, São } \\
\text { Pedro da Aldeia, Iguaba Grande, Arraial do Cabo e Armação de Búzios }\end{array}$ \\
\hline $\begin{array}{l}\text { Serrana } \\
805.627 \text { hab. }\end{array}$ & $\begin{array}{l}\text { Carmo, Cantagalo, São Sebastião do Alto, Santa Maria de Madalena, Duas Barras, Cor- } \\
\text { deiro, Macuco, Sumidouro, Bom Jardim, Trajano de Morais, Nova Friburgo, Teresópolis, } \\
\text { Petrópolis e São José do Vale do Rio Preto }\end{array}$ \\
\hline $\begin{array}{l}\text { Centro-Sul Fluminense } \\
272.227 \text { hab. }\end{array}$ & $\begin{array}{l}\text { Comendador Levy Gasparian, Paraíba do Sul, Vassouras, Engenheiro Paulo de Frontin, } \\
\text { Miguel Pereira, Paty de Alferes, Três Rios, Areal, Sapucaia e Mendes }\end{array}$ \\
\hline $\begin{array}{l}\text { Costa Verde } \\
243.500\end{array}$ & Paraty, Angra dos Reis e Mangaratiba \\
\hline $\begin{array}{l}\text { Médio Paraíba } \\
855.193\end{array}$ & $\begin{array}{l}\text { Barra do Piraí, Barra Mansa, Itatiaia, Pinheiral, Piraí, Porto Real, Quatis, Resende, Rio } \\
\text { Claro, Rio das Flores, Valença e Volta Redonda }\end{array}$ \\
\hline
\end{tabular}

Fonte: Ceperj, 2014; IBGE, Cidades, 2010.

\section{Contexto e distribuição espacial dos impactos ambientais}

Nesta seção, apresenta-se a distribuição dos impactos, problemas e conflitos, bem como o contexto em que ocorrem, levando-se em conta a análise integrada segundo as regiōes de governo. A relação com o contexto torna-se relevante para colaborar com o entendimento das singularidades e dar sentido à problemática identificada.

\subsection{Região Metropolitana Fluminense}

O perfil metropolitano de concentração populacional afirmou-se no passado remoto e eclodiu dos anos 1940 em diante, atraindo um grande fluxo de migrantes, predominantemente nordestinos. Essa concentração metropolitana culminou nos anos 1960, consolidando-se nas décadas seguintes (Galvão, 2009; Ribeiro e O’Neill, 2012;). Em 2010, a Região Metropolitana fluminense contava com um contingente populacional de 11.945.532 habitantes (IBGE, 2010).

Seus principais problemas ambientais, relacionados ao intenso processo de metropolização, estão associados à proliferação de loteamentos sem infraestrutura, falta de saneamento e de destinação adequada do lixo, precariedade dos transportes públicos, baixo nível de renda e de escolaridade da população. Nas áreas de baixadas, verificam-se, com frequência, enchentes e inundaçôes nos períodos chuvosos (Costa, 2001).

No entorno da Baía de Guanabara, coexistem diferentes usos e ocupaçôes: usos residenciais, intensa urbanização, eixos viários, diversas indústrias, refinarias, atividades comerciais e de serviços. Em suas margens, encontra-se o núcleo metropolitano - a cidade do Rio de Janeiro. No seu espelho d'água, circulam transatlânticos e embarcaçôes de pescadores artesanais, bem como aquelas que dão apoio às atividades de extração de petróleo, desenvolvidas principalmente na bacia de Campos. 
Todas as funçōes citadas vêm contribuindo para a ocorrência de inúmeros impactos na Baía de Guanabara, tais como: lançamento de esgoto sanitário sem tratamento e de lixo de todo tipo, com origem nos afluentes da baía ou jogados diretamente no espelho d'água; óleo das embarcaçōes; aterro em suas margens; e retirada de manguezais. As atividades existentes, somadas com aquelas que se estão instalando em suas bordas, em função da nova lógica econômica, vêm afetando, de forma drástica, as atividades de pesca artesanal.

A instalação do Complexo Petroquímico do Rio de Janeiro (Comperj) no município de Itaboraí teve início em 2008, sendo considerado o maior empreendimento da Petrobras e um dos maiores do mundo, envolvendo a instalação de várias indústrias (Secretaria de Estado do Ambiente, 2015). ${ }^{2}$ Com essa construção, novos problemas emergiram na porção leste do núcleo metropolitano, potencializando os problemas já existentes no entorno da baía. Nessa área, chama-se também a atenção para as alterações vindouras no município de Maricá, em função da especulação imobiliária e dos inúmeros empreendimentos previstos (Prefeitura de Maricá, 2016).

O emissário submarino do Comperj, cujas obras estão em fase final, transportará os dejetos químicos provenientes do Complexo Petroquímico, em Itaboraí, lançando-os a dois quilômetros da praia de Itaipuaçu. Ainda haverá outro emissário para efluentes, de construção polêmica e cujo duto também passa por Maricá (Prefeitura de Maricá, 2016).

O processo de licenciamento dos diferentes empreendimentos que integram o Comperj identificou um conjunto de impactos que atingem diversos elementos do ambiente físico e daquele relacionado à sociedade, provocando acentuada alteração na paisagem, intenso fluxo migratório para a área e expansão urbana (Secretaria de Estado do Ambiente, 2015).

O Arco Metropolitano é outro grande projeto levado a efeito nessa porção do território fluminense, ligando o Comperj ao Porto de Itaguaí e passando pelos municípios de Duque de Caxias, Nova Iguaçu, Japeri, Seropédica, Magé, Guapimirim e Queimados. Esse trajeto oferece a vantagem de reduzir os custos de transporte ao encurtar distâncias, o que beneficia a cidade do Rio de Janeiro, por desviar os impactos do fluxo de transporte de cargas. Sua construção impactou quatro unidades de conservação de uso sustentável: a Flona Mário Xavier, a APA Rio D’Ouro, a APA Retiro e a APA do Guandu. Entretanto, alguns estudos apontam para seu potencial em termos de crescimento econômico, considerando esse o projeto viário mais importante para o estado do Rio de Janeiro. Sua implantação é avaliada como um fator favorável ao estabelecimento de indústrias, notadamente aquelas ligadas às atividades de petróleo e gás. Faz parte, portanto, das iniciativas de logística de inserção do Porto de Itaguaí e demais empreendimentos (Secretaria do Estado do Ambiente, 2015).

Sua construção, contudo, gerou um número elevado de impactos à natureza e à sociedade. A referida rodovia também corta numerosas áreas de baixa ocupação e com vazios urbanos. Essas áreas merecem especial atenção, pois podem atrair intenso fluxo de população, tornando-se, assim, vulnerável a ocupaçōes desordenadas (Secretaria de Estado do Ambiente, 2015).

Na porção oeste da Regiáo Metropolitana fluminense, outro grande empreendimento - o Porto de Itaguaí - vem atraindo um grande fluxo de população e novas atividades, provocando um novo surto de crescimento nesse município e nas adjacências. O Porto de Itaguaí vem-se destacando em

2 Este estudo compõe o Projeto ZEE/RJ, que foi elaborado pelo Consórcio Cobrape-Oikos, coordenado pela Secretaria de Estado e Ambiente (SEA). 
importância, sendo considerado um dos mais modernos da América Latina e o primeiro concentrador de cargas do Atlântico Sul (Unacoop, 2011). No município de Itaguaí, também estão em desenvolvimento vários projetos, dentre os quais o que envolve a Petrobras, a Companhia Siderúrgica Nacional $(\mathrm{CSN})$ e a Gerdau, prevendo a construção de um porto compartilhado, no qual se instalará o apoio à exploração do pré-sal (idem, ibidem).

Seropédica é outro município que integra essa região de governo e que tem, na produção de areia para a construção civil, especialmente no rio Guandu, importante atividade. No entanto, nesse município, ocorrem inúmeros casos de extração ilegal. Embora seja uma atividade que assume grande relevância econômica, abastecendo $70 \%$ da construção civil da Região Metropolitana, nem sempre é realizada com respeito às as leis do licenciamento ambiental, que incluem as condicionantes e um plano de recuperação. Entre os problemas ambientais causados por essa atividade, verificam-se impacto visual, assoreamento dos rios e abandono dos terrenos (crateras), deixando para trás um grande passivo ambiental. A retirada de areia, realizada por dragas, interfere diretamente no fluxo de água subterrâneo (Marques, 2006), podendo atingir o lençol freático (aquífero Paranaense) e dando origem a grandes lagoas. Pesquisas realizadas na área ressaltam que essa ação representa um grave problema ambiental, pois os aquíferos, ao serem atingidos, afetam a bacia do rio Guandu, fonte de abastecimento de água do Grande Rio (Tubbs et al., 2011). Essa questão chama a atenção também pela capacidade de gerar conflitos graves, pois as atividades relacionadas à extração de areia, praticadas em um número considerável de rios, geram impactos ambientais que conflitam com as atividades agrícolas desenvolvidas nesse município (Unacoop, 2011).

Outra questão que se deve considerar diz respeito ao lixão de Gramacho, situado no município de Duque de Caxias e que recebeu, durante 35 anos, o lixo da cidade do Rio de Janeiro e dos municípios vizinhos. Considerada uma área de grande impacto, com a formação de chorume, originado da decomposição do lixo depositado, constituiu-se, durantes muitos anos, em um grande causador da poluição da Baía de Guanabara. Em 2012, procedeu-se à transferência do lixão de Gramacho para o Centro de Tratamento de Resíduos, em Seropédica, e à recuperação da área, transformando-se o lixão em um aterro com o reaproveitamento do gás e atuando em um longo processo de eliminação do chorume (Ribeiro, 2016).

\subsection{Região do Médio Paraíba}

A região do Médio Paraíba, área do eixo Rio-São Paulo, apresenta intenso fluxo de mercadorias e de pessoas, com a dinâmica econômica vinculada à expansão industrial, destacando-se as indústrias automobilística e siderúrgica. Inclui-se entre as áreas que receberão o maior número de empreendimentos no estado do Rio de Janeiro. Conta ainda com vários projetos de grande porte, em fase de implantação, ligados principalmente à indústria automobilística. Seus problemas ambientais estão relacionados ao desmatamento, à poluição dos rios e à expansão de periferias urbanas, além de pressão sobre o patrimônio natural: o Parque Nacional de Itatiaia. Em Volta Redonda, há graves problemas decorrentes do despejo em grande quantidade de lixo químico, contaminando o solo e o lençol freático.

Em Volta Redonda, um estudo que teve por objetivo analisar a vulnerabilidade da região e os riscos ambientais envolvidos no que diz respeito ao sistema de drenagem, mostrou as alterações ocorridas na rede de drenagem, os processos erosivos e suas implicações nas enchentes havidas (Castro e Peixoto, 2015). A pesquisa concluiu que os processos erosivos e os movimentos de massa são importantes, mas 
confirmou a situação de risco ambiental nesse município. Tais riscos, associados a obras e intervençōes urbanas "que, em princípio, organizariam novos espaços, potencializam os impactos existentes, além de criar novos" (Castro e Peixoto, 2015, p. 192). Levou-se em conta também que os efluentes domésticos e industriais apresentam situaçôes de risco ambiental para a população da referida cidade.

\subsection{Região das Baixadas Litorâneas}

A área do conjunto das Baixadas Litorâneas se destaca pela expansão do setor de turismo e lazer, assim como o de segunda residência, recebendo também os impactos provenientes das açóes ligadas ao setor de petróleo. Nas últimas décadas, apresentou intenso crescimento populacional, observando-se um grande descompasso entre a demanda e a oferta de serviços públicos.

Seus principais problemas ambientais dizem respeito à ocupação desordenada e ao uso inadequado em ambientes considerados frágeis, como manguezais, praias, costōes e restingas. O município de Rio das Ostras vem sofrendo intenso processo de erosão em sua linha de costa, o que altera sobremaneira a praia, derruba árvores e destrói edificaçōes, conforme se observa na Figura 1.

Outro elemento importante está relacionado ao impacto nos ambientes marinhos, com a ocorrência de desastres ambientais que têm origem nos vazamentos de óleo nas atividades de exploração de petróleo. Em novembro de 2011 e março de 2012, verificou-se um vazamento de óleo causado pela empresa Chevron, ocorrido em uma sonda de perfuração em Campo de Frade, na bacia de Campos (Nitahara, 2013).

Figura 1. Processos erosivos na linha da costa desmatando e destruindo as edificaçôes: Rio das Ostras
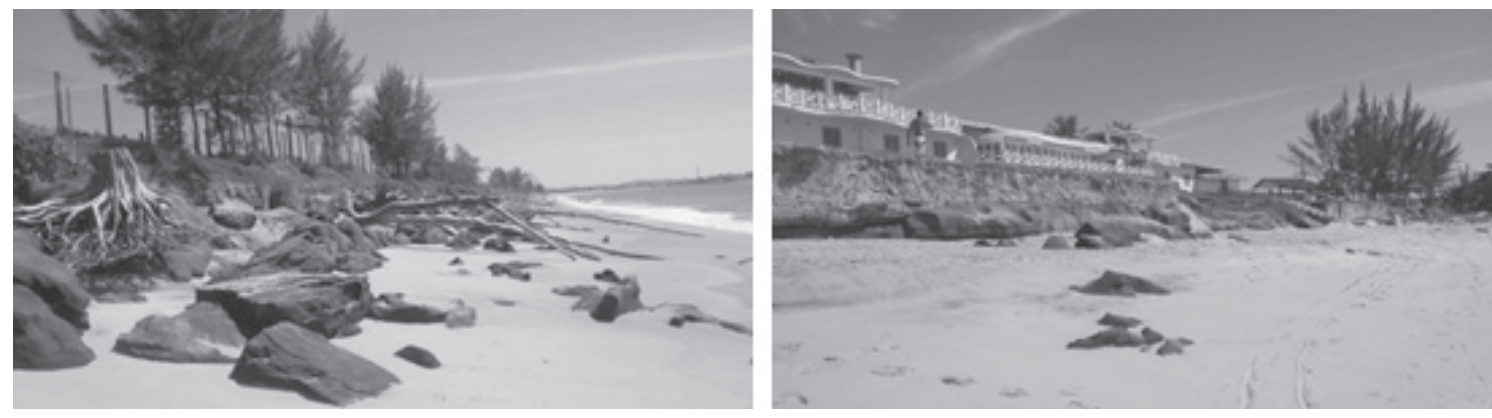

Fonte: Arquivo pessoal da autora, fevereiro de 2016.

A BR-101 é uma das mais importantes rodovias federais do país, cortando praticamente todo o litoral brasileiro. Por atender a importantes centros e áreas econômicas, gera intenso fluxo de bens e mercadorias. Essa rodovia pode ser considerada um eixo de grande impacto, causado pelos inúmeros acidentes envolvendo mortes e longos engarrafamentos. Embora atendendo às áreas mais importantes do país na produção de petróleo e nas atividades turísticas, com relevante papel socioeconômico, só recentemente vem sendo finalizada sua duplicação (Figura 2). 
Figura 2. BR 101: engarrafamento em Rio das Ostras e duplicação em Rio Bonito
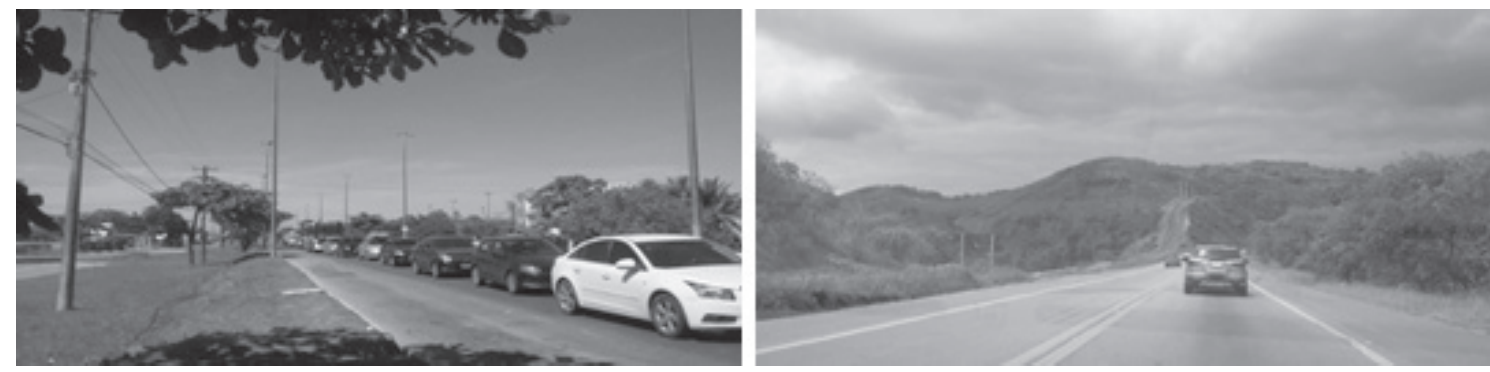

Fonte: Aquivo pessoal da autora, fevereiro de 2016.

\subsection{Região Centro-Sul Fluminense}

A região que compreende o Centro-Sul Fluminense sofreu, durante anos, as consequências da decadência da produção de café. Atualmente, sua economia se baseia nas atividades agropastoris tradicionais, renovadas pelas atividades turísticas fundamentadas em seu patrimônio histórico e cultural, oriundas da cafeicultura.

Três Rios é um importante centro regional, enquanto Vassouras se destaca como centro educacional de expressão nacional. A construção da usina hidroelétrica de Simplício no município de Três Rios é responsável pelo maior impacto ambiental nessa região. O município de Paty do Alferes vem-se destacando pela produção de tomates, embora o uso intensivo e sem controle dos agrotóxicos seja motivo de preocupação.

Nessa área, verifica-se uma perda muito grande da vegetação natural, encontrando-se predomínio das pastagens ralas, muito sujeitas a queimadas nas épocas de seca, e ocorrendo diminuição dos corpos hídricos (Secretaria de Estado do Ambiente, 2011). Essa questão motivou a criação, no município de Vassouras, do projeto "Cadê a Água de Andrade Costa?", desenvolvido pela ONG Vale Verdejante, com o apoio da Assessoria e Planejamento para o Desenvolvimento (Asplande), em face do risco de se extinguirem algumas nascentes e de diminuírem as águas desses córregos. Essa questão assume relevância pelo fato de muitas nascentes e pequenos rios dessa porção do território fluminense serem contribuintes de afluentes maiores do Paraíba do Sul. A caracterização da área no referido projeto destaca esse problema, conforme se observa no seguinte excerto:

Relatos na área relembram que no passado o córrego de Andrade Costa fluía com mais água do que hoje, propiciando banhos em cachoeiras e alagados. Comumente, mesmo na época de chuvas, o volume do córrego não é comparável em volume ao que existia antigamente. Concluímos que, apesar de ser um córrego de expressão local, assume um papel diferenciado, pois é um contribuinte de um dos afluentes do rio Paraíba do Sul integrando-se, desta maneira, a uma bacia hidrográfica de relevância regional e estadual (Asplande e Vale Verdejante, 2014).

O relatório também comprovou que o pequeno núcleo urbano de Andrade Costa, com uma população em torno de 1 mil habitantes, não conta com um sistema adequado de esgotamento sanitário, 
o que prejudica a qualidade de vida da população. O conjunto de problemas ambientais encontrados nessa pequena localidade levou a uma situação crítica, em face de eventuais consequências imprevisíveis (Asplande e Vale Verdejante, 2014).

Figura 3. Andrade Costa - Pastagem com capim ralo/queimadas na estação seca. Rodovia RJ-131, solos erodidos, com a formação de voçorocas

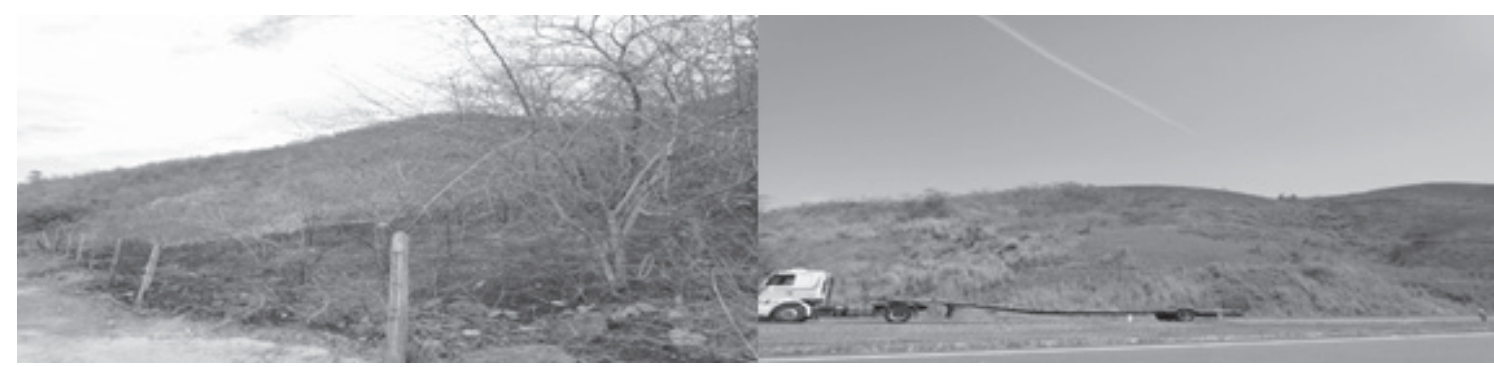

Fonte: Arquivo pessoal da autora, setembro de 2014.

Outra questão relevante diz respeito ao rio Paraíba do Sul, que margeia o território nas regiōes do Médio Paraíba, Centro-Sul, Noroeste e Norte fluminenses, e sofre outros impactos além dos citados, decorrentes do lançamento de esgoto doméstico das cidades ribeirinhas e de várias indústrias. $\mathrm{O}$ efeito desses danos repercute na poluição de suas águas, com a mortandade de peixes e a diminuição da atividade de pesca artesanal. Não menos graves são as alterações verificadas em seu curso e em sua foz.

\subsection{Região da Costa Verde}

O litoral sul do estado, denominado Regiáo da Costa Verde, é uma área que tem passado por transformações decorrentes da expansão dos setores turístico e imobiliário, da implantação de grandes indústrias e das atividades ligadas à logística de transporte global, com a expansão portuária e a construção da Usina Nuclear de Angra 3 (Zuleika, 2012).

Nessa região, há previsão de um grande aporte de recursos financeiros para atender à implantação de inúmeros projetos (Secretaria de Estado do Ambiente, 2015). Entretanto, tais empreendimentos envolvem muitos impactos ambientais e conflitos com as populaçôs tradicionais e as atividades econômicas. Para se ter uma ideia da magnitude dos problemas ambientais que afetam essa área, pode-se citar a lista de impactos relacionados à "Fase de Implantação e Operação de Angra 3", conforme apresentada pela Eletronuclear no processo de licenciamento. $\mathrm{O}$ referido estudo chama a atenção ainda para o raio de ação dos impactos de Angra 3 e para sua proximidade com o Núcleo Metropolitano, área mais densamente ocupada do estado do Rio de Janeiro (Zuleika, 2012).

As instalaçôes termonucleares são empreendimentos polêmicos que devem ser considerados com muito cuidado, por apresentarem impacto elevado e de alto risco. Por essa razão, há exigência legal de planos de evacuação na hipótese de ocorrência de acidentes nucleares. Essa é outra grande 
preocupação na região, devido às dificuldades de acesso, em função da logística da área, que conta com a Rodovia Rio-Santos como único eixo de circulação (Aguiar, 2013; Unacoop, 2011).

A Costa Verde destaca-se ainda pelo aumento da relevância das atividades turísticas, hoje sobressaindo-se no ERJ pela presença de muitos hotéis de luxo, estabelecimentos que atraem turistas de várias áreas do território nacional e do exterior. Apesar dos benefícios que a atividade proporciona em termos de emprego e de renda, deve-se observar que a implantação do turismo está associada a conflitos de uso com as populações tradicionais e a impactos relacionados a aterros nos manguezais, desmatamento, privatização da orla e pressão sobre os serviços urbanos, mais precisamente nos locais em que o fluxo turístico é mais elevado (SEA/INEA, 2015).

A região também é importante para a produção pesqueira, especialmente a pesca artesanal. Suas condições naturais são propícias a essa atividade, o que a coloca em posição de destaque no conjunto do ERJ. Contudo, os vazamentos de óleo na baía da Ilha Grande causam sério impacto ambiental, especialmente à comunidade pesqueira e às populações tradicionais (Aguiar, 2013; Unacoop, 2011). Outro impacto para a atividade de pesca é a retirada de lama para aprofundar os canais que dão acesso a navios de grande calado (SEA/INEA, 2015).

Os problemas ambientais nessa área são bastante complexos. Relacionam-se à expansão de periferias com o uso inadequado do solo urbano, à falta de infraestrutura de saneamento básico, à poluição de baías e à redução de espécies de peixe (Motta, 2011), bem como ao desmatamento em diversas áreas e aterros em manguezais (Unacoop, 2011). Nos últimos anos, a área por sérios problemas de deslizamentos de terra no município de Angra dos Reis, prejudicando um grande número pessoas e atividades (Aguiar, 2013; SEA/INEA, 2015).

A expansão das atividades econômicas provoca ainda prejuízo às comunidades tradicionais, incluindo quilombolas, indígenas, caiçaras e agricultores familiares, levando à perda de suas terras, a conflitos e à alteração de seu modo de vida. O risco de as práticas dessas comunidades se extinguirem é muito grave, pois equivaleria a se perder grande parte dos conhecimentos que dominam, especialmente aqueles relacionados ao meio ambiente. A permanência dessas comunidades tradicionais colabora e garante a sustentabilidade, melhorando o equilíbrio entre as atividades desenvolvidas no conjunto da regiāo (Aguiar, 2013; Unacoop, 2011).

\subsection{Região Noroeste Fluminense}

A antiga área de produção cafeeira, situada na Região Noroeste Fluminense, parece ainda ressentir-se do processo de erradicação dos cafezais. Além da baixa renda de sua população, apresenta problemas de enchentes, inundações e degradação dos solos (Costa, 2001). Em 2003, verificou-se um desastre ambiental de grande proporção, proveniente do derramamento de mais de 1 bilhão de litros de resíduos tóxicos de uma indústria em Cataguases, no rio Pomba, afluente da margem esquerda do rio Paraíba do Sul, afetando-o da confluência à foz.

O Noroeste Fluminense destaca-se na agropecuária, com ênfase para a produção leiteira, e notabiliza-se pelas atividades ligadas às rochas ornamentais (granito e mármore) que se destinam à construção civil. É o principal produtor do estado, com maior relevância para os municípios de Santo 
Antônio de Pádua, Italva e Itaperuna, que abrangem duzentas pedreiras e cem serrarias ${ }^{3}$ em atividade. Nessa região, há exploraçôes ilegais responsáveis por desmatamento e descarte de rejeitos em áreas impróprias, ocasionando impacto ao ambiente. $\mathrm{O}$ modelo de produção com baixa eficiência gera uma série de impactos ambientais: dano à saúde dos trabalhadores, problemas dos efluentes gerados nas serrarias, uso de explosivos (causando ruídos e tremores à população), alteração da paisagem e dos corpos hídricos, poluição do ar, entre outros (Silvestre et al., 2014).

\subsection{Região Norte Fluminense}

A região Norte Fluminense, considerada uma das mais problemáticas do estado do Rio de Janeiro, apresenta inúmeros problemas que advêm dos impactos provenientes das atividades relacionadas à exploração do petróleo, à implantação de grandes empreendimentos e à expansão desordenada de suas cidades. A área apresenta intenso fluxo de pessoas, bens e mercadorias, associado aos problemas de expansão urbana acelerada, como, por exemplo, a precariedade do saneamento básico e do transporte, e o uso inadequado do solo urbano.

A Região Norte Fluminense passou por um processo de modernização do setor sucroalcooleiro, mas mantém suas discrepâncias econômicas e sociais, por não ter levado essas mudanças aos demais setores de atividades da região (Prado, 2015). Contudo, ela teve seu desenvolvimento alavancado a partir dos anos 1970, graças às operaçôes da Petrobras em Macaé.

Essa região vem-se destacando pela retomada do crescimento econômico e pela implantação de vários empreendimentos associados às atividades de petróleo e gás, as quais, contudo, têm suscitado polêmica devido ao significativo impacto ambiental provocado. O Complexo Logístico Industrial Farol Barra do Furado, na divisa de Quissamã e Campos dos Goytacazes, o Complexo do Superporto do Açu, em São João da Barra, e o Terminal Portuário Offshore Canaã, no município de São Francisco do Itabapoana, são exemplos de empreendimentos formados por vários projetos previstos para a área.

Esses projetos foram os grandes responsáveis pelas rápidas transformaçôes que se desencadearam no Norte Fluminense, além de terem causado um grande número de conflitos e impactos no ambiente natural e na sociedade. Como exemplo do impacto causado por essas transformaçóes, observa-se que, com o Projeto do Porto do Açu, o município de São João da Barra passará a ter, como principais atividades, aquelas ligadas à função portuária, enquanto as atividades tradicionalmente tidas como mais importantes (agrícolas e pecuárias) não mais funcionarão como setor econômico básico. Esse projeto muita polêmica, com o questionamento e a solicitação de revisão do licenciamento ambiental (Pacheco, 2015). Prado (2015, p. 125) cita ainda os impactos sociais causados por esse projeto: "A desapropriação em São João da Barra é um nítido exemplo de ações corporativas, legitimadas pelo Estado, que negligenciaram a história dos lugares, a dimensão simbólica/afetiva das relações sociais e, principalmente, os aspectos materiais dos residentes".

3 As serrarias integram o processo de exploração de pedras ornamentais e são responsáveis pelo acabamento final das rochas. 
Prado também destaca o processo de violência que acompanhou as ações de implantação, levando inúmeras famílias a serem deslocadas de suas casas e reassentadas em outras áreas. Os impactos ambientais geram foram muitos, conforme se identifica no processo de licenciamento dos diferentes empreendimentos do Complexo do Açu (Secretaria de Estado do Ambiente, 2015). Entretanto, o projeto vem apresentando um freio em sua inserção, devido à crise na EBX, holding responsável por sua implantação (Pacheco, 2015).

Outros pontos dignos de destaque são o rápido crescimento populacional e a expansão urbana em Macaé (Ribeiro e O’Neill, 2015) como centro das atividades ligadas à exploração de petróleo, conforme se verifica no estudo realizado por Cadena (2012):

[...], o crescimento populacional gerou uma série de outras transformações na geografia macaense, como a intensificação da mobilidade espacial da população (migraçôes e mobilidade interna), os impactos ambientais de toda ordem, as mudanças em sua paisagem urbana, entre outras. A segunda transformação de destaque em Macaé se relaciona ao intenso processo de urbanização socioespacial no município. Nos últimos trinta anos, a taxa de urbanização elevou-se de $72 \%$ em 1980 para $98 \%$ em 2010. A rápida urbanização provocou sérios impactos na configuração do sítio urbano macaense, sobretudo caracterizados pelo processo de periferização da população mais pobre e pela expansão da favelização, acompanhada do vertiginoso aumento das tensões sociais e da violência urbana [...].

As demandas surgidas com as atividades de petróleo em Macaé, especialmente no que diz respeito à moradia, levaram o município a um crescimento extraordinário da população, revelado pelas maiores taxas verificadas no estado: 11,25\% entre 2000 e 2010 (Ribeiro e O’Neill, 2012).

\subsection{Região Serrana Fluminense}

A chamada Região Serrana Fluminense é uma área que se reestrutura em torno de novas organizaçôes industriais, aliando itens tradicionais e modernos, como a agricultura, o turismo, o centro de informática e a tendência às agroindústrias alimentar e têxtil, ambas apoiadas na presença de um grande mercado metropolitano próximo. As enchentes e os deslizamentos de terra ocorridos em 2011 e 2013, que configuraram um desastre ambiental de grandes proporções, foram traumáticos para a população, e as atividades econômicas da região, especialmente nos municípios de Petrópolis, Teresópolis e Friburgo, ainda se ressentem dos impactos sofridos. Além disso, desmatamento, uso inadequado do solo urbano/rural, uso intensivo de agrotóxicos, ocupação desordenada das encostas, falta de fiscalização dos órgãos públicos e desvios de recursos públicos também estão no centro das catástrofes.

Petrópolis vem ampliando, com sucesso, um centro de estudos e desenvolvimento de sistemas de informática, denominado Petropólis-Tecnópolis (Costa Jr., 2012). Essa iniciativa, baseada em empresas de tecnologia, é capaz de modificar a estrutura econômica da cidade, com a vantagem de reunir atividades com menor grau de impacto ambiental. 
No que diz respeito à agricultura desenvolvida na Região Serrana, nota-se a prática intensiva, durante todo o ano, de diversos produtos hortícolas, além da produção de frutas, muitas vezes recorrendo-se a modernos sistemas de produção. Isso envolve o uso de grande quantidade de insumos, cujos produtos químicos são avaliados como inadequados ao ambiente. Essas práticas trazem consigo o risco de poluiçãoo das águas e do solo, comprometendo também a qualidade ambiental. As características da agricultura nessas áreas apontam para a necessidade de acompanhamento e orientação técnica de práticas conservacionistas e de manejo, bem como para o controle do uso de agrotóxicos e de produtos químicos (Barros, 2015).

Igualmente, é necessário dispensar cuidados com as áreas rurais, cuja densidade populacional é elevada, com baixa infraestrutura de saneamento. Esse é o caso, por exemplo, da bacia do Rio Grande, em Friburgo, que, através de pesquisa realizada, identificou, "na maioria das sub-bacias, valores de coliformes totais e fecais acima do permitido pela legislação, o que compromete a utilização da água para o consumo humano. Esse quadro é reflexo da falta de uma rede de esgoto na área" (Barros, 2015, p. 156).

\section{Problemas ambientais decorrentes da urbanização}

O estado do Rio de Janeiro sobressai-se pelo predomínio da população urbana sobre a rural e pela elevada concentração populacional na Região Metropolitana. Destaca-se também pela maior taxa de urbanização do país, tendo em vista que $96,6 \%$ de seus habitantes vivem nas cidades, perfazendo um total de 15.446.996 pessoas (Ribeiro e O’Neill, 2015). A urbanização é considerada o processo mais relevante em termos de organização do território fluminense, sendo a metropolitanização uma de suas características principais. Entretanto, verificou-se que esse fenômeno, com tamanha dimensão, não conta com o apoio contínuo de um órgão de Estado dedicado a questôes urbanas, observando-se, nesse aspecto, uma fraca atuação em termos de políticas públicas urbanas (idem).

Não obstante, do ponto de vista ambiental, a urbanização é responsável por mudanças significativas na paisagem e no ambiente físico, bem como por um conjunto de problemas de alta gravidade no estado do Rio de Janeiro, como desmatamento, poluição de recursos hídricos, pressão sobre áreas de proteção ambiental, expansão de periferias urbanas, favelização, aterros em ambientes frágeis, falta de saneamento, poluição do ar, falta de serviços públicos, enchentes, deslizamento de terra, baixa renda da população, pobreza, desemprego, baixo nível de escolaridade, falta de fiscalização, falta de segurança e violência, entre muitos outros. Um traço marcante no crescimento das cidades fluminenses é que esse processo nem sempre veio acompanhado de bem-estar da população.

Os problemas ambientais urbanos encontram-se disseminados pelas diversas regiōes do território fluminense, associados ao crescimento das atividades econômicas em áreas urbanas e ao intenso fluxo de população oriunda das áreas rurais. As formas de construção e vivência nas cidades, especialmente naquelas de maior populaçãao e de alta densidade demográfica, como, por exemplo, na área metropolitana e nas periferias de cidades como Angra dos Reis, Macaé, Teresópolis, Petrópolis, Friburgo, Volta Redonda e Rio Bonito, entre outras, não atenderam a muitas das condições requeridas para a satisfação de suas necessidades. Outra grande preocupação no que diz respeito às cidades mais populosas do estado do Rio de Janeiro é o abastecimento de água. As cidades exigem água em grande quantidade, seja para as atividades econômicas, como as indústrias, seja para as necessidades da população. Assim, a proteção dos mananciais que suprem esses centros urbanos mais populosos já se tornou uma questão estratégica. 
Merece destaque o fato de que, nessas áreas urbanas, especialmente as maiores cidades e as de características metropolitanas, foram criados ambientes em que as conexōes e os laços afetivos com a natureza estavam enfraquecidos. Algumas abordagens que permitem a identificação dessas perdas, pensando-se em açōes que visam ao maior equilíbrio entre as ocupaçōes humanas e a natureza, sempre serão bem-vindas. No entanto, precisam ser trazidas para o centro das discussões.

\section{Interação dos impactos ambientais e reflexões sobre políticas públicas}

Os numerosos problemas ambientais no território fluminense preocupam porque a permanência deles pode comprometer a qualidade de vida, a saúde da população, atingir patrimônios naturais protegidos pelas convençôes nacionais e internacionais, bem como potencializar os impactos entre si, criando cenários de uma degradação ambiental mais grave e, em consequência, interferir negativamente no crescimento econômico do estado do Rio de Janeiro.

No caso do ERJ, chamamos a atenção para uma particularidade quanto aos Relatórios de Impacto Ambiental (RIMA), que tendem a subestimar os danos causados, uma vez que fazem a avaliação por empreendimento, e não para o conjunto de projetos existentes em uma mesma área. Conforme mencionado, estão em curso, no estado, grandes projetos formados por vários empreendimentos, como é o caso do Comperj, do Complexo do Superporto do Açu, do Terminal Portuário Offshore Canaã, do Complexo Logístico Industrial Farol Barra do Furado e do Porto de Itaguaí.

Após avaliar os impactos causados ao meio ambiente físico e à sociedade, provenientes dos diversos empreendimentos que se instalaram ou se encontram em processo de implantação, foram identificadas sete áreas de maior vulnerabilidade, em função do número e da gravidade que apresentam. Entre elas, destacamos cinco situadas ao longo do litoral e no eixo Rio-São Paulo, cujos impactos estão diretamente associados aos grandes empreendimentos, à instalação de indústria pesada e às ocupaçōes inadequadas em ambientes já degradados ou frágeis (Figura 4). Ainda foram identificadas duas áreas situadas nas Regiōes Serrana e Noroeste Fluminense cujos recortes espaciais envolvem atividades tradicionais que, ao serem dinamizadas nas últimas décadas, também geraram sérios impactos e conflitos ambientais. Trata-se de áreas que já apresentam suscetibilidade à erosão, solos erodidos e impactos potencializados por atividades altamente agressoras ao ambiente.

Nesses conjuntos destacados, é relevante considerar que os efeitos dos impactos devem ser percebidos de forma integrada, levando-se em conta sua complexidade. Neles, são evidentes as transformaçôes no território e na paisagem, surgidas de forma muito rápida e trazendo consequências graves a vários elementos do ambiente físico e da sociedade. Do ponto de vista espacial, esses impactos se caracterizam pela grande extensão e pela possibilidade de afetar áreas mais remotas. A importância de se apontarem essas áreas decorre, como já mencionado, do risco de potencializar problemas e impactos entre si, de gerar cenários mais graves, com tendência à degradação ambiental. Merecem, portanto, cuidados especiais. A preocupação com os recortes indicados se prende ao fato de que, ao desencadear desastres e degradação, o desenvolvimento socioeconômico regional e estadual pode tornar-se seria- 
mente comprometido. Os recortes espaciais apresentados na Figura 4 são tão somente um esboço a ser aprimorado por novas pesquisas e trabalhos de campo.

A grande pressão sobre a infraestrutura dos municípios que não estão preparados para as novas demandas é uma questão relevante. De fato, o poder público municipal, em sua maioria, não está tecnicamente capacitado, mostrando-se, do ponto de vista político, muito frágil como promotor do desenvolvimento econômico ou diante do poder das grandes empresas multinacionais que se instalam no âmbito dos municípios. Nesses municípios fluminenses em geral, os empreendimentos se desenvolveram sem discussão prévia acerca do destino das populações direta ou indiretamente afetadas e das atividades tradicionais que se desenvolviam nessas áreas e com as quais conflitam.

Esses dois aspectos conduzem à reflexão sobre as dificuldades de se atuar de forma planejada e de se promoverem ações que integrem esses megaprojetos às atividades municipais e regionais, articulando, de fato, um processo de desenvolvimento. Embora planejados pelo governo estadual, percebe-se que esses complexos de empreendimentos não encontram sinergia entre si ou, então, tais interdependências não estão claramente explicitadas.

Acresce que, devido ao fenômeno das mudanças climáticas, muitas áreas poderão ter, como consequência, o avanço das águas sobre o território litorâneo, onde foi priorizada a maioria dos projetos considerados estruturantes do estado (Secretaria de Estado do Ambiente, 2015). Assim, são evidentes os riscos que tais empreendimentos podem enfrentar no futuro e os prejuízos que podem trazer para as atividades econômicas que se implantaram nessa área ou estão em processo de implantação. Esses danos não recairão somente sobre as empresas, afetarão também o poder público e a população local ou aquela que se deslocou ao se sentir atraída pelas oportunidades oferecidas. De acordo com Suzana Kahn, os grandes projetos previstos para o estado do Rio de Janeiro vão sujar ainda mais a base industrial do estado nos próximos anos, porque o planejamento para o crescimento econômico do estado do Rio está centrado numa economia que não leva em consideração os efeitos da mudança climática (Melo, 2011; Secretaria de Estado do Ambiente, 2012).

O estado do Rio de Janeiro possui uma extensão significativa do território que é considerada patrimônio natural e, no conjunto, são 446.000 hectares de áreas estaduais protegidas, sendo 19 unidades de conservação de proteção integral (parques, reservas biológicas e estação ecológica), 14 unidades de uso sustentável (áreas de proteção ambiental e reserva extrativista marinha), além de cinco parques nacionais (INEA, 2015). Essas áreas, quando próximas à implantação de novas atividades econômicas e de grandes empreendimentos, correm um risco muito elevado de desencadear problemas relacionados ao desmatamento e à perda da biodiversidade, entre outros impactos. Esse é outro ponto crucial a ser observado, pois as consequências dessas pressões não se restringem exclusivamente à localização de determinado empreendimento e, por isso, requerem uma visão espacial integrada.

Nas diversas regiōes fluminenses também se verificam iniciativas positivas em que se buscam desenvolver atividades que apresentem uma relação mais harmoniosa com a natureza. Esse é o caso, por exemplo, das atividades ligadas ao turismo, em área de patrimônio natural e histórico-cultural, e à produção de produtos orgânicos, na Região Serrana, sendo essas ações de grande relevância para o desenvolvimento com sustentabilidade do estado. Tais práticas, contudo, também ficam expostas a impactos e conflitos. Necessitam, da mesma forma que outras, de cuidados, especialmente quanto ao controle mais efetivo do uso de agrotóxicos e à ausência de saneamento rural. 
Embora esteja previsto, para as próximas décadas no estado do Rio de Janeiro, um grande aumento das atividades de exploração de petróleo, notadamente aquelas associadas à exploração do pré-sal, instalou-se no uma séria crise, provocada por fatores internos e externos, que afetou diretamente o andamento das obras desses empreendimentos e, por conseguinte, todos os setores de atividades dessas áreas. As consequências desse freio ainda terão de ser avaliadas, porém já se observam seus efeitos no desemprego, no fechamento de lojas e serviços ligados ao petróleo, bem como no enfraquecimento dos serviços públicos prestados à população. Outra situação que deve passar por um processo de paralisação é o projeto do Porto do Açu, cuja empresa responsável, a EBX, recuou na aplicação de investimentos.

O certo é que, apesar de esses projetos colaborarem para o crescimento econômico das regiōes do ERJ, também criam muitos problemas para os quais o Poder Público, que os apoiou, tem mostrado baixa capacidade de articular soluções e coordenar ações que evitem seu surgimento e/ou a minimização de seus efeitos. Episódios de enchentes e chuvas intensas em curto período têm-se repetido no território fluminense, onde os problemas ambientais já estavam deflagrados e ocasionaram desastres ambientais de consequências severas. Essas catástrofes trouxeram acentuada perda material, sofrimento para as populações atingidas e espantosos gastos por parte do Poder Público. Em consequência, há o risco de retrocesso no nível de desenvolvimento das regiōes afetadas.

\section{Conclusão}

As avaliações realizadas nas diferentes regiōes de governo apontam para o aumento da vulnerabilidade à degradação e para a ocorrência de desastres em diversas áreas do território fluminense. Entretanto, o ERJ, em virtude de sua dimensão territorial, de suas características naturais e da formação socioespacial, tem condições excepcionais de se desenvolver de modo sustentável e harmônico com a natureza, reduzindo o impacto ambiental e o risco de desastres. Alterar as prioridades e repensar novos caminhos representam a melhor alternativa para o ERJ, direcionando-o progressivamente para a escolha de atividades econômicas que apresentem maior possibilidade de conciliação com o meio ambiente e o bem-estar de sua população. O futuro do ERJ dependerá dessa capacidade de se empreenderem atividades sob uma nova perspectiva e de se encontrarem soluçôes que reduzam as emissões de gases de efeito estufa e os impactos e conflitos ambientais com menor vulnerabilidade.

No processo de planejamento, a compreensão e a espacialização dos problemas, os impactos e conflitos ambientais constituem peça-chave, revelando-se essenciais para se desenvolver uma postura preventiva, diminuindo, assim, a ocorrência desses danos, bem como auxiliando a administração pública, de modo que possa atuar menos nas situaçóes de emergência. $O$ freio verificado nas atividades econômicas, em função da crise pela qual o estado e o país passam, em que pese o prejuízo que acarreta, pode ser um momento oportuno para se repensarem as iniciativas em novas bases. 
Figura 4. Visão integrada dos impactos ambientais

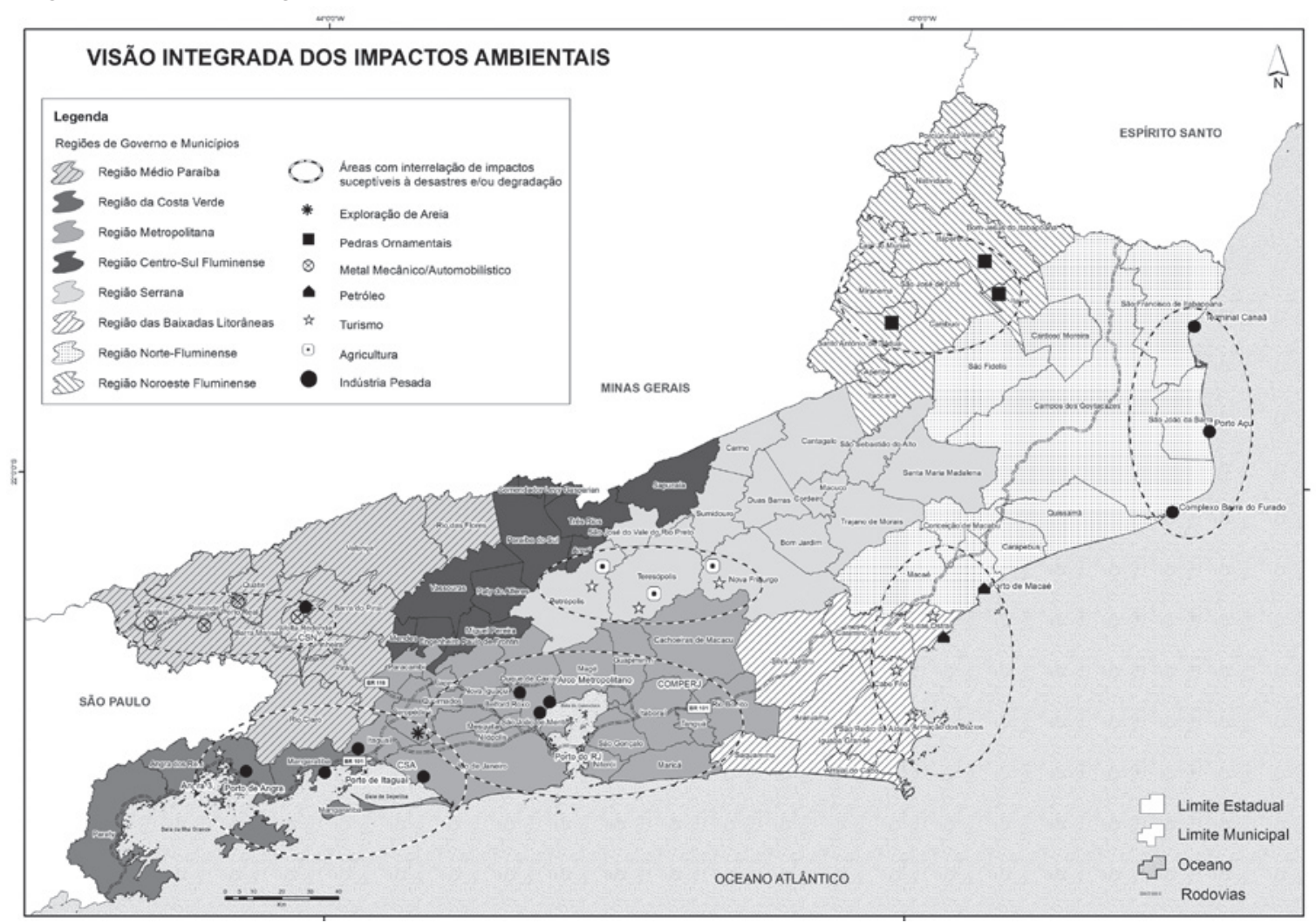

Fonte: a autora, 2016.

\section{Referências}

ABREU, Maurício de. “A evolução urbana do Rio de Janeiro”. Rio de Janeiro: Iplan Rio/Zahar, 1987. $147 \mathrm{p}$.

AGRA FILHO, Severino Soares. Conflitos ambientais e os instrumentos da politica nacional de meio ambiente (tese). UFRJ, 2008.

AGUIAR, Tereza Coni. Metodologia de análise socioeconômica para planejamento ambiental: uma contribuição à interação sociedade/natureza (tese). UFF, 2012.

- "Local impacts and global concerns: environmental issues in the area of Ilha Grande and Sepetiba Bays, Rio de Janeiro - Brasil”. How will rapid global changes transform civilizations? Proceedings of the 2013: Conference International Society for the Comparative Study of Civilizations (ISCSC). Califórnia: Connie Lamb, Brian Wages, Brigham Young University e Peter Hecht, K-12 Educational Innovator. 
ASPLANDE e VALE VERDEJANTE. Relatório Técnico. Cadê a água de Andrade Costa? Rio de Janeiro: Asplande/Vale Verdejante, 2014.

BARROS, Regina Cohen. "Verificação da qualidade da água dos rios da bacia do Rio Grande (Nova Friburgo/RJ). In FERNANDES, Ulisses et al. (orgs.). Velhos saberes, novas abordagens: a geografia à luz da contemporaneidade. 1 ed. Rio de Janeiro: Gramma, 2015. 230p.

BOLEA, Maria-Teresa Estevan. "Las evaluaciones de impacto ambiental”, Cuadernos del Centro Internacional de Formación em Ciencias Ambientales (CIFCA), Madri, 1977.

BRASIL. "Coletânea de legislação de direito ambiental. Constituição Federal”. In MEDAUAR, Odete (org.). RT Minicódigos. 7 ed. São Paulo: Revista dos Tribunais, 2008. 118p.

BREDARIOL, Celso Simões. Conflito ambiental e negociação para uma política local de meio ambiente (tese). UFRJ, 2001.

CADENA, Alberto. "Crescimento populacional e os vetores de expansão urbana em Macaé-RJ”. In MARAFON, Glaucio José e RIBEIRO, Miguel Angelo (orgs.). Revisitando o território fluminense $I V$. Rio de Janeiro: Gramma, 2012.

CASTRO, Cleber Marques e PEIXOTO, Maria Naise de Oliveira. "Urbanização, vulnerabilidades e riscos ambientais associados aos sistemas de drenagem: uma análise a partir de Volta Redonda (RJ)". In FERNANDES, Ulisses et al. (orgs.). Velhos saberes, novas abordagens: a geografia à luz da contemporaneidade. 1 ed. Rio de Janeiro: Gramma, 2015. 230p.

CEPERJ. Fundação Centro Estadual de Estatísticas, Pesquisas e Formação de Servidores Públicos do Rio de Janeiro. Governo do Estado do Rio de Janeiro. Estado do Rio de Janeiro: regióes de governo e municipios - 2014. Disponível em: http://www.ceperj.rj.gov.br/ceep/info_territorios/Reg\%20 Gov_2013.pdf. Acesso em: 24 fev. 2016.

CHEW, Sing C. World Ecological Degradation: accumulation, urbanization, and deforestation 3000 B.C.-A.D. 2000. Nova Iorque: AltaMira Press, 2001.

— e AGUIAR, Tereza Coni. "Book reviews". Tradução de Tereza Coni Aguiar. Comparative Civilizations Review, n. 71, 2014, pp. 115-8.

CHRISTOFOLETTI, Antonio. "Impactos no meio ambiente ocasionados pela urbanização no mundo tropical”. In SOUZA, M. A. A. de (org.). Natureza e sociedade hoje. 3 ed. São Paulo: Hucitec, 1997.

COELHO, Maria Célia Nunes. "Impactos ambientais em áreas urbanas: teorias, conceitos e métodos de pesquisa”. In GUERRA, Antônio José Teixeira e CUNHA, Sandra Baptista da (orgs.). Impactos ambientais urbanos no Brasil. Rio de Janeiro: Bertrand Brasil, 2001.

COSTA, Helder. Enchentes no estado do Rio de Janeiro: uma abordagem geral. Rio de Janeiro: SEMADS, 2001.

COSTA JUNIOR, Aluísio de Araújo. "Arranjos produtivos locais no estado do Rio de Janeiro: o exemplo da Petrópolis-Tecnópolis”. In MARAFON, Glaucio José e RIBEIRO, Miguel Angelo (orgs.). Revisitando o Território Fluminense IV. Rio de Janeiro: Gramma, 2012.

CUNHA, Ícaro. "Conflito ambiental em águas costeiras: relação porto-cidade no canal de São Sebastiāo”, Ambiente \& Sociedade, Rio de Janeiro, v. VI, n. 2, jul.-dez. 2003. 
GALVÃO, Maria do Carmo Corrêa. Percursos geográficos. Rio de Janeiro: Lamparina PPGG/UFRJ, 2009.

IBGE. Projeto Gerenciamento Costeiro. Diagnóstico Ambiental do Litoral de Santa Catarina. Relatório Final setores 1 e 2. Dominio da sociedade: problemas socioeconômicos, setores 1 e 2. Contrato IBGE/MERCOSUL-SED/SC. Rio de Janeiro: IBGE, jun. 1997.

—. Cidades. Rio de Janeiro: IBGE, 2010. Disponível em: http://www.cidades.ibge.gov.br/xtras/ home.php. Acesso em: mar. 2016.

INEA. Instituto Estadual do Ambiente. Unidades de Conservação da Natureza (UCs). Rio de Janeiro, 2015. Disponível em: http://www.inea.rj.gov.br/Portal/Agendas/BIODIVERSIDADEEAREASPROTEGIDAS/UnidadesdeConservacao/index.htm\&lang=PT-BR. Acesso em: jan. 2016.

MARICÁ (RJ). Prefeitura Municipal de Maricá, 2016. "Obras do emissário submarino entram em estágio final em Itaipuaçu”. Disponível em: http://maricainfo.com/2015/04/27/obras-do-emissario-submarino-entram-na-reta-final-em-itaipuacu.html. Acesso em: 24 jan. 2016.

MARQUES, Eduardo Duarte. Impactos da mineração de areia na bacia sedimentar de Sepetiba, RJ: estudo de suas implicaçōes sobre as águas do aquifero Piranema (tese). UFF, 2010.

MELO, Liana. "O futuro próximo é marrom, diz Suzana Kahn, subsecretária de Economia Verde do Rio", O Globo, Rio de Janeiro, "Economia”, 7 mar. 2011.

NASCIMENTO, Flávio Rodrigues do. O fenômeno da desertificação. Goiânia: UFG, 2013. 240p.

NITAHARA. Akemi. "Chevron vai pagar R 95 milhôes para compensar danos ambientais de vazamentos no campo de Frade". Agência Brasil. Disponível em: http://memoria.ebc.com.br/agenciabrasil/noticia/2013-09-13/chevron-vai-pagar-r-95-milhoes-para-compensar-danos-ambientais-de-vazamentos-no-campo-de-frade. Acesso em: fev. 2016.

PACHECO, Wedson Felipe Cabral. "Porto do Açu, o 'X' da questão: a implantação no município de São João da Barra (RJ)”. In: MARAFON, Glaucio José e RIBEIRO, Miguel Angelo (orgs.). Revisitando o território fluminense V. 1 ed. Rio de Janeiro: Gramma, 2015. 376p.

PRADO, Fellipe Silva. "A emergência de novas territorialidades a partir da implantação do Superporto do Açu: o reassentamento Vila da Terra em São João da Barra (RJ)". In MARAFON, Glaucio José e RIBEIRO, Miguel Angelo (orgs.). Revisitando o território fluminense V. Rio de Janeiro: Gramma, 2015, p. 111-129.

RIBEIRO, Miguel Ângelo e O'NEIL, Mônica. "Considerações sobre a dinâmica populacional fluminense: contrastes entre a metrópole e o interior. In MARAFON, Glaucio José (org.). Revisitando o território fluminense IV. Rio de Janeiro: Faperj/Gramma, 2012.

_ . "Contrastes entre a metrópole e o interior fluminense a partir do urbano e do rural". In FERNANDES, Ulisses et al. (orgs.). Velhos saberes, novas abordagens: a geografia à luz da contemporaneidade. 1 ed. Rio de Janeiro: Gramma, 2015.239p.

RIBEIRO, Raquel. "De Gramacho a Seropédica”. Radis, comunicação e saúde, Rio de Janeiro, n. 162, mar. 2016. Disponível em: http://www6.ensp.fiocruz.br/radis/conteudo/de-gramacho-seropedica. Acesso em: mar. 2016.

RIO DE JANEIRO. Secretaria de Estado do Ambiente. O estado do ambiente: indicadores ambientais do Rio de Janeiro. Org. Julia Bastos e Patrícia Napoleão. Rio de Janeiro: SEA/ INEA, 2011. 
- Plano estadual sobre mudança do clima. Rio de Janeiro: SEA, 2012.

- Secretaria de Estado do Ambiente. Elaboração do zoneamento ecológico econômico do estado do Rio de Janeiro. Sintese: tendências de ocupação e uso territorial. Consórcio Ecológico Cobrape-Oikos. Rio de Janeiro, jul. 2015.

—. SEA/INEA. Diagnóstico do setor costeiro da Baía de Ilha Grande. Subsídios à elaboração do zoneamento ecológico-econômico costeiro. Rio de Janeiro: SEA/INEA, 2015. Disponível em: http:// www.inea.rj.gov.br/cs/groups/public/documents/document/zwew/mdcz/ - edisp/inea0073532. pdf. Acesso em: fev. 2016.

SILVESTRE, Carolina Pereira et al. "A produção de rochas ornamentais no Noroeste do estado do Rio de Janeiro: Santo Antônio de Pádua e Italva”, Revista Tamoios, São Gonçalo-RJ, ano 10, n. 1, jan.-jun. 2014, pp. 114-127.

STEPHAN, Gustavo. "Poluição doméstica: a principal agressão ao rio Paraíba do Sul”. O Globo, "Ciência”, Rio de Janeiro, 18 dez. 2012.

TUBBS, Décio et al. "Impacto da mineração de areia sobre a química das águas subterrâneas, Distrito Areeiro da Piranema, municípios de Itaguaí e Seropédica, Rio de Janeiro”. Revista Brasileira de Geociências, São Paulo, v. 41, n. 3, set. 2011. Disponível em: http://wwwppegeo.igc.usp.br. Acesso em: fev. 2016.

TUCCI, Carlos Eduardo Morelli. "Impactos ambientais urbanos no Brasil”. Prefácio. In GUERRA, Antonio José Teixeira e CUNHA, Sandra Baptista da (orgs.). Impactos ambientais urbanos no Brasil. Rio de Janeiro: Bertrand Brasil, 2001.

UNACOOP. "Diagnóstico territorial: território da baía da Ilha Grande, Rio de Janeiro". União das Associações e Cooperativas Usuárias do Pavilhão 30, Ministério do Desenvolvimento Agrário, Secretaria do Desenvolvimento Territorial Convênio SDT-MDA, UNACOOP. Rio de Janeiro, nov. 2011.

ZULEIKA, Alimandro Rosa. "Espaço e questão portuária: o exemplo de Angra dos Reis". In RIBEIRO, Miguel Ângelo e MARAFON, Glaucio José (orgs.). Revisitando o território fluminense IV. Rio de Janeiro: Faperj/Gramma, 2012. 
ERRATA

No capítulo "Uma visão integrada dos impactos ambientais no estado do Rio de Janeiro", do livro Revisitando o território fluminense VI, na página 65, onde se lê:

"Uma visão integrada dos impactos ambientais no estado do Rio de Janeiro."

Leia-se:

"Uma visão integrada dos impactos ambientais no estado do Rio de Janeiro"

[nota de rodapé excluída].

No mesmo capítulo, na página $71, \S 2^{\circ}$, onde se lê:

“(Secretaria de Estado do Ambiente, 2015)."

Leia-se: “(Secretaria de Estado do Ambiente, 2015).2”

"Este estudo compõe o Projeto ZEE/RJ, que foi elaborado pelo Consórcio Cobrape-Oikos, coordenado pela Secretaria de Estado e Ambiente (SEA).” [nota de rodapé incluída].

No mesmo capítulo, na página 83, na fonte do mapa, onde se lê:

"Luiza Boechat, 2016."

Leia-se: “a autora, 2016.”. 